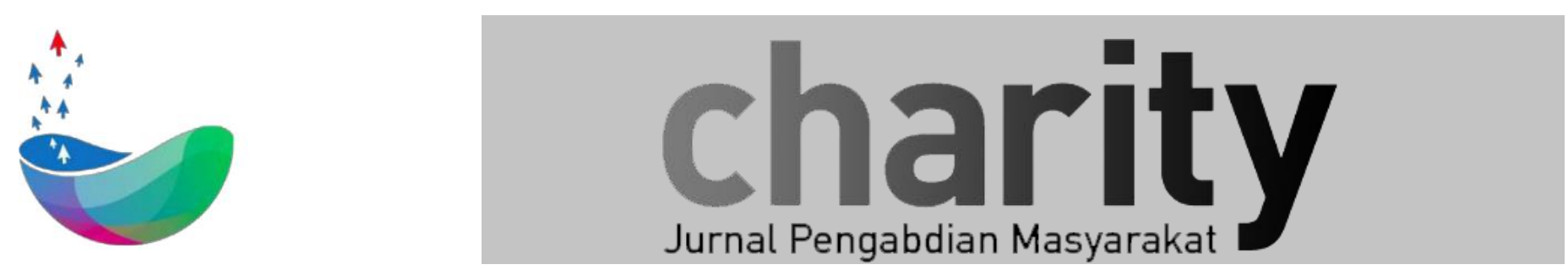

\title{
Penyusunan Kalender Masa Tanam Untuk Optimasi Produk Sayuran Organik Dalam Mendukung Program Diversifikasi Olahan Pangan B2SA Kelompok Wanita Tani Kreatif Permata
}

\author{
Sri Suryani ${ }^{1}$, Yuliant Sibaroni ${ }^{2}$, Dyas Puspandari ${ }^{3}$ \\ ${ }^{1}$ Teknik Informatika, Fakultas Informatika, Universitas Telkom \\ ${ }^{2}$ Teknik Informatika, Fakultas Informatika, Universitas Telkom \\ Teknik Informatika, Fakultas Informatika, Universitas Telkom \\ 4 srisuryani@telkomuniversity.ac.id, yuliant@telkomuniversity.ac.id, diyaspuspandari@telkomuniversity.ac.id
}

\section{INFO ARTIKEL}

Diterima 21 Juni 2019

Direvisi 28 Juni 2019

Disetujui 30 Agustus 2019

Tersedia Online 6 Juli 2020

\begin{abstract}
ABSTRAK
Seiring dengan berkurangnya lahan terbuka di desa Lengkong karena program pengembangan kawasan perumahan, maka program Kawasan Rumah Pangan Lestari (KRPL) yang telah dicanangkan oleh pemerintah menjadi sulit untuk diimplementasikan. Sehingga dengan program pemberdayaan wanita di desa lengkong dan optimalisasi lahan terbuka dan lahan pekarangan yng ada, terbentuklah Kelompok Wanita Tani Kreatif Permata di desa Lengkong Setelah berjalan 10 bulan, KWT Kreatif mulai dapat meningkatkan produksinya, dan mulai dapat memenuhi warga masyarakat sekitar dalam bentuk konsumsi sayur dan ikan, selain mentah juga diolah menjadi beragam produk makanan inovatif. Olahan pangan tersebut diharapkan dapat memperhatikan aspek Bergizi, Berimbang, Sehat dan Aman (B2SA). Salah satu hal mendasar selain untuk ketahanan pangan, perlu adanya olahan pangan di KWT Kreatif adalah produksi sayuran yang berlebih, dan kadang-kadang proporsinya belum seimbang. Tetapi saat ini, program tersebut belum dijalankan oleh KWT Kreatif, karena keterbatasan pengetahuan, peralatan dan pendanaan untuk menuju olahan pangan berbasis B2SA. Oleh karena itu perlu suatu metode untuk optimasi volume produksi sayurannya melalui penyusunan kalender masa tanam sayuran organik KWT Kreatif Permata.
\end{abstract}

Keyword: KWT, Sayuran, Olahan Pangan, Kalender Masa Tanam.

Korespondensi:

Direktorat Penelitian dan Pengabdian Masyarakat, Universitas Telkom

J1. Telekomunikasi No. 1, Terusan Buah Batu, Bandung, 40257

Negara :Indonesia.

E-mail : charity@telkomuniversity.ac.id

ORCID ID: -

Penulis Pertama: Sri Suryani

https://doi.org/10.25124/charity.v2i2.2041

Paper_reg_number 2041 (C) The Authors. Published by Directorate of Research and Community Service, Telkom University.

This is an open access article under the CC BY-NC 4.0 license (https://creativecommons.org/licenses/by-nc/4.0/) 


\section{Pendahuluan}

Desa Lengkong merupakan salah satu dari 6 desa yang ada di Kecamatan Bojongsoang. Usaha pemanfaatan lahan terbuka di desa Lengkong sulit dilakukan, karena lahan terbuka yang luas tersebut biasanya dikelola untuk pertanian dan dimiliki oleh warga, dan kecenderungan untuk dijual ke pengembang perumahan sangat tinggi. Sehingga lama kelamaan lahan terbuka untuk penghijauan akan habis.

Terdapat upaya pengembangan budidaya tanaman sayuran dan perikanan oleh kelompok warga. Sayuran yang dihasilkan selain untuk dikonsumsi oleh anggota kelompok, juga dijual kepada warga lain. Kelompok-kelompok yang dibentuk di pedesaan dengan pemberdayaan perempuan dinamakan Kelompok Wanita Tani (KWT).

Kegiatan-kegiatan yang dilakukan KWT Kreatif merupakan salah satu bentuk dukungan terhadap program pemerintah yaitu program KRPL (Kawasan Rumah Pangan Lestari). KRPL ini secara penuh dikelola oleh kelompok wanita tani yang didalamnya meliputi pengelolaan administrasi, pengelolaan rumah bibit, budidaya sayuran, buah dan ikan serta pengelolaan hasilnya yang bisa membantu dalam sektor ekonomi anggota. Untuk kegiatan pengolahan hasil pertanian, kelompok wanita tani mengutamakan hasil lokalita daerah tersebut, yaitu buah kaboca, pakcoy, selada, sosin, kale dan lain-lain. Dengan berbahan dasar sayuran, ikan dan buah tersebut, kelompok wanita tani Kreatif dapat melakukan pengolahan pangan seperti kue basah, kue kering, lauk pauk, dan lain-lain.

Kelompok-kelompok yang dibentuk di pedesaan dengan pemberdayaan perempuan dinamakan Kelompok Wanita Tani (KWT). Pembentukan KWT ini sejalan dengan program pemerintah yang ingin melibatkan kaum perempuan untuk mengembangkan sektor pertanian dalam negeri. Pemerintah pusat akan mentransformasi kelembagaan KWT supaya berkembang menjadi kelompok usaha tani yang mandiri [1].

KWT Kreatif dibentuk berdasarkan Surat Keputusan Kepala Desa Lengkong no 501/10/05/XI/2017 pada akhir tahun 2017. Sedangkan kegiatan KWT mulai aktif pada tanggal 10 Januari 2018 dan saat ini, produk yang dihasilkan dari KWT Kreatif adalah produk sayuran dan ikan. Sebagian besar sayuran dihasilkan melalui sistem tanam menggunakan media tanah, sebagaian kecil lainnya dihasilkan melalui sistem tanam aquaponik. Produk ikan juga dihasilkan dari sistem tanam aquaponik ini dimana kotoran ikan digunakan sebagai pupuk organik bagi pertumbuhan sayuran. Teknik penanaman sayuran yang dilakukan oleh KWT Kreatif adalah penanaman sayuran organik, yaitu pupuk yang digunakan adalah pupuk cair organik dengan berbahan dasar sampah organik dan menghindari penggunaan pestisida. 


\section{Permasalahan dan Solusi Yang Ditawarkan}

\subsection{Permasalahan}

Banyaknya varian produk sayuran KWT Kreatif selain memberikan keunikan tersendiri juga memunculkan tantangan tersendiri yaitu terkait waktu yang optimal untuk penanaman benih dan kuantitas bibit yang harus ditanam. Hal ini sangat berkaitan dengan ketidakteraturan jadwal panen sayuran yang masih terjadi dan juga berkaitan dengan penyerapan pasar untuk jenis sayuran tertentu. Jadwal panen yang belum teratur mempersulit warga lain yang ingin membeli produk sayuran dari KWT ini secara rutin.

Permasalahan lainnya yang muncul adalah kurangnya promosi terhadap produk sayuran yang dihasilkan oleh KWT ke masyarakat luar. Hal ini membuat masyarakat sekitar menjadi kurang mengenal dengan baik jenis-jenis produk sayuran yang dihasilkan oleh KWT Kreatif, sehingga sering terjadi, hasil panen sayuran KWT akhirnya hanya dikonsumsi oleh anggota KWT saja karena tidak terserap pasar dengan baik. Hal ini membuat kondisi kas keuangan KWT menjadi stagnant dan perkembangan usaha budidaya sayuran yang dilakukan lambat. Ini merupakan hal yang ironi, mengingat kebutuhan sayuran masyarakat sebenarnya cukup besar. Permasalahan ini berdampak pada pengelolaan operasional KWT dan tergambar pada gambar grafik arus kas KWT, sebagai contoh tahun 2018

Arus Kas KWT Kreatif Permata 2018

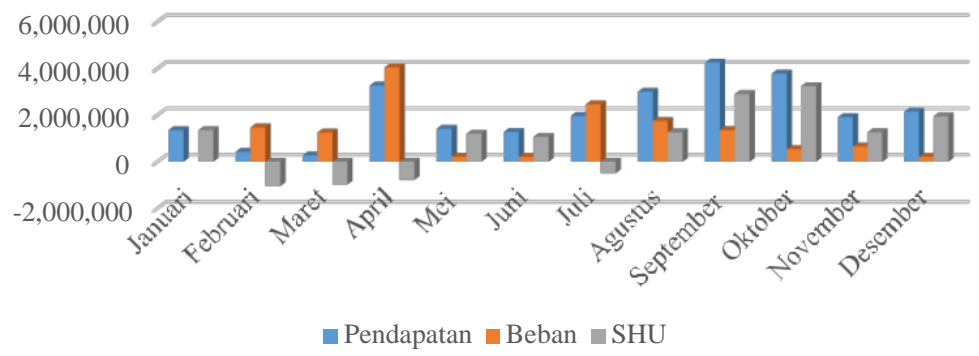

Gambar 1. Arus Kas KWT selama tahun 2018

\subsection{Solusi Yang Ditawarkan}

Berdasarkan permasalahan dan peluang yang muncul, program yang diusulkan untuk menjadi solusinya. Salah satu metode optimasi produk sayuran KWT Kreatif yang diusulkan adalah pembuatan kalender waktu tanam sayuran yang optimal. Kalender ini dibuat dengan memperhatikan waktu panen ideal untuk setiap sayuran, luas lahan untuk menanam sayuran serta kebutuhan pasar untuk setiap jenis sayuran dengan menggunakan teknik prediksi. Dari proses ini, selain memberikan luaran utama berupa kalender waktu tanam sayuran, luaran lainnya adalah berupa rekomendasi terkait jenis sayur yang harus ditanam dan kebutuhan luas lahan yang masih bisa dikembangkan. Kedua luaran ini sangat penting untuk rencana pengembangan KWT Kreatif dalam masa mendatang.

Selain itu kebutuhan data pasar terkait produk sayuran di area desa Lengkong tentunya sangat diperlukan untuk kebutuhan pengembangan usaha dari KWT Kreatif ini. Selain meneliti jumlah pasar, survei juga diperlukan untuk melihat anemo masyarakat akan jenis-jenis produk sayuran baru yang belum biasa di lingkungan mereka. Beberapa jenis sayuran baru tersebut pada saat ini juga menjadi salah satu unggulan dari KWT Kreatif. 


\section{Metode Pelaksanaan}

Untuk mencapai tujuan bahwa transformasi KWT Kreatif menjadi Kelompok Tani yang mandiri yaitu dapat meningkatkan peran serta produktivas wanita tani sebagai pengurus rumah tangga maupun perannya sebagai pelaku usaha dalam upaya peningkatan pendapatan dan pemenuhan kebutuhan pangan keluarga serta menuju pencapaian program ketahanan pangan. Maka dikembangkan beberapa metode kegiatan yang memanfaatkan potensi yang dimiliki oleh KWT Kreatif . Adapun metode yang digunakan dalam pelaksanaan pengabdian masyarakat ini yaitu pendampingan pembuatan kalender masa tanam

Untuk mendukung kegiatan tersebut, dilakukan sosialisasi dan pendampingan tentang penyusunan kalender masa tanam untuk mengelola budidaya produk sayuran, agar olahan pangan tetap kontinu diproduksi. Adapun gambaran iptek yang ditransfer disajikan pada Gambar 1.

\section{Hasil dan Pembahasan}

\subsection{Analisis Kebutuhan}

Kegiatan pengabdian masyarakat diawali dengan pendataan kebutuhan KWT Kreatif Permata terkait dengan pemanfaatan produk sayuran KWT Kreatif Permata, kekontinuan produk dan pemasarannya. Berdasarkan hasil pendataan diperoleh informasi bahwa, produk sayuran dipengaruhi oleh beberapa faktor, antara lain musim dan minat konsumen. Sehingga sangat diperlukan strategi terkait kekontinuan produk, pemasaran dan penganekaragaman produk KWT Kreatif Permata menjadi produk olahan pangan, agar kegiatan operasional KWT tetap berjalan. Dengan adanya kebutuhan tersebut, maka dalam kegiatan pengabdian masyarakat ini diusulkan program diversifikasi olahan pangan produk sayuan organik KWT Kreatif Permata RT/RW 03/07 desa Lengkong.

\subsection{Sosialisasi}

Setelah dilakukan pendataan kebutuhan masyarakat sasar, dilakukan sosialisasi kegiatan pengabdian masyarakat diversifikasi olahan pangan berbahan dasar sayuran organik yang merupakan produk dari KWT Kreatif Permata dalam rangka mendukung program pemerintah tentang ketahanan pangan dengan tersedianya produk olahan pangan B2SA. Untuk mendukung program tersebut, diperlukan kecukupan stock sayuran, sehingga selain kegiatan tersebut, juga dilakukan sosialisasi program pembuatan kalender masa tanam. Program sosialisasinya disajikan pada gambar 2. Pembuatan kalender masa tanam merupakan salah satu program yang terdapat pada gambaran Ipteks yang ditransfer ke masyarakat sasar, yang tersajikan pada gambar 3 .

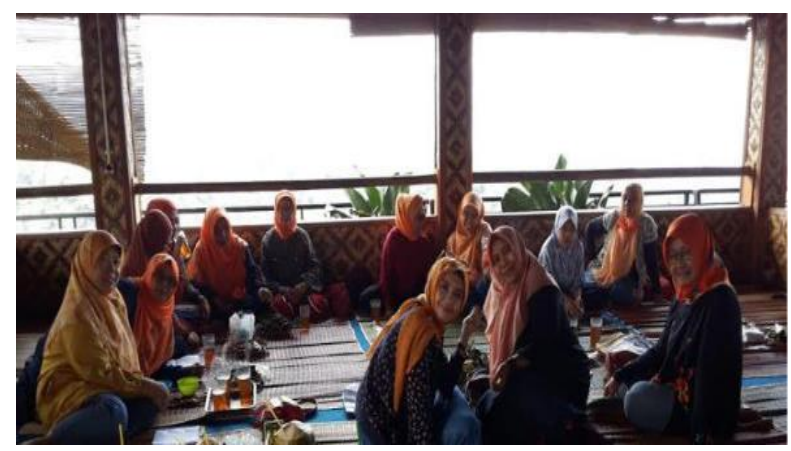

Gambar 2. Sosialisasi Program Pembuatan Kalender Masa Tanam 


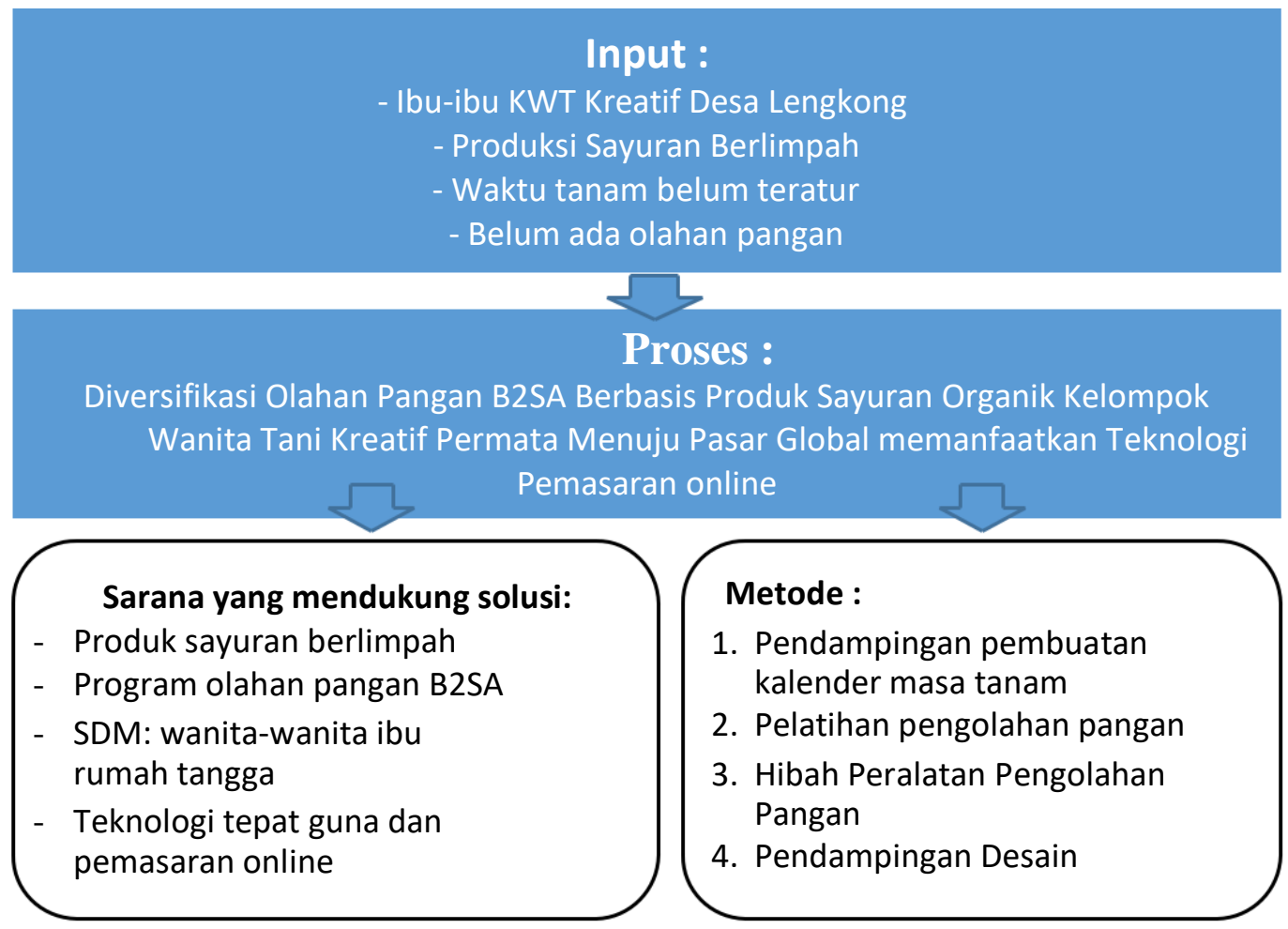

Metode akhir: Pendampingan pembuatan kalender masa tanam, pemasaran online dan olahan pangan beserta pembuatan kemasan

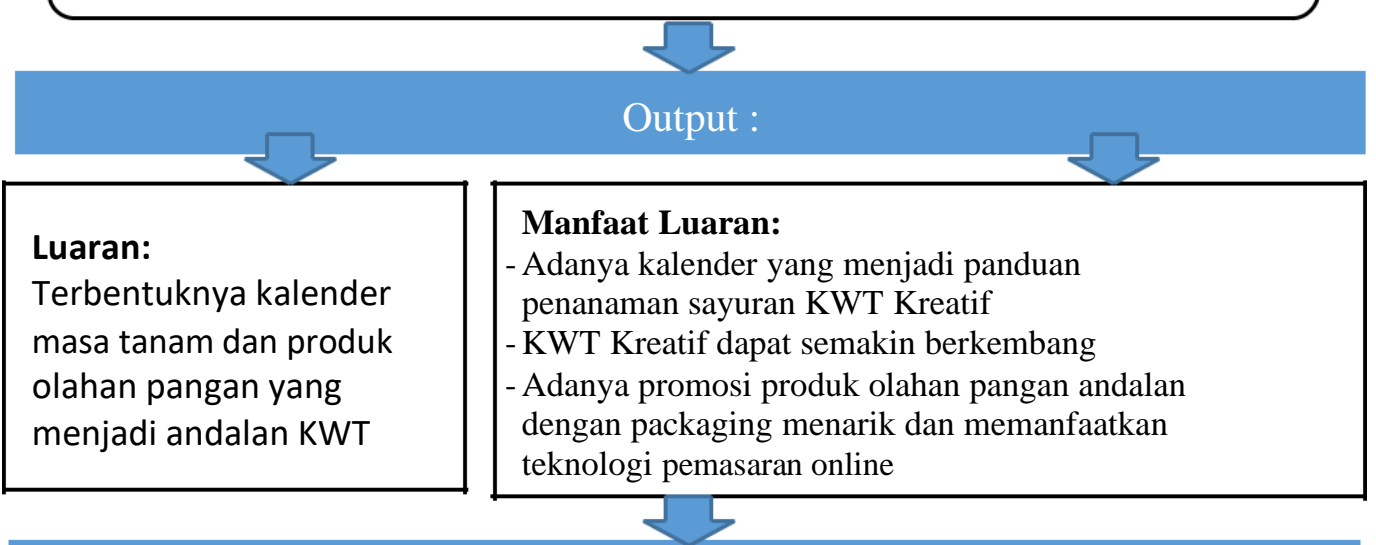

Outcome : Kalender masa tanam untuk optimasi produk sayuran sebagai bahan dasar olahan pangan KWT Kreatif menuju pasar global

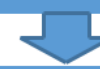

\section{Evaluasi:}

Optimasi masa tanam produk sayuran KWT Kreatif

Kontinuitas dan kualitas produk olahan pangan dan packagingnnya

Pemanfaatan teknologi pemasaran online untuk pemasaran produk

Gambar 3. Gambaran Ipteks yang ditransfer

\subsection{Pelatihan dan Pendampingan}


Setelah dilakukan sosialisasi program, dilakukan kegiatan pendampingan dan pelatihan penentuan metode penanaman dengan kalender masa tanam yang memperhatikan musim dan minat konsumen. Asumsi yang digunakan adalah masa panen minimal 1 bulan maksimal 1,5 bulan. Adapun sebagian kalender masa tanam yang diusulkan adalah sebagai berikut

Tabel 1. Kalender Masa Tanam Sayuran KWT Kreatif Permata

\begin{tabular}{|c|c|c|c|c|c|c|}
\hline Bulan & Musim & Permintaan & $\begin{array}{c}\text { Jenis } \\
\text { Sayuran }\end{array}$ & Media & Volume & Keterangan \\
\hline \multirow{15}{*}{ Januari } & \multirow{15}{*}{ Hujan } & Cukup & Kangkung & $\begin{array}{l}\text { Kotak } \\
\text { tanah }\end{array}$ & 2 & Di lahan terbuka \\
\hline & & Banyak & Bayam hijau & $\begin{array}{l}\text { Kotak } \\
\text { tanah }\end{array}$ & 0 & $\begin{array}{l}\text { Musim hujan, di } \\
\text { lahan terbuka, } \\
\text { bayam mudah } \\
\text { rusak }\end{array}$ \\
\hline & & Sedikit & $\begin{array}{l}\text { Bayam } \\
\text { Merah }\end{array}$ & $\begin{array}{l}\text { Kotak } \\
\text { tanah }\end{array}$ & 0 & $\begin{array}{l}\text { Musim hujan, di } \\
\text { lahan terbuka, } \\
\text { bayam mudah } \\
\text { rusak }\end{array}$ \\
\hline & & Cukup & Cabe Rawit & $\begin{array}{l}\text { Kotak } \\
\text { tanah }\end{array}$ & 1 & Di lahan terbuka \\
\hline & & Sedikit & Sosin & Polybag & 30 & $\begin{array}{l}\text { Setelah } 2 \\
\text { minggu polybag } \\
\text { harus dipindah } \\
\text { ke bawah }\end{array}$ \\
\hline & & Sedikit & Tomat & $\begin{array}{l}\text { Kotak } \\
\text { Tanah }\end{array}$ & 0 & $\begin{array}{l}\text { Musim hujan, di } \\
\text { lahan terbuka, } \\
\text { tomat mudah } \\
\text { rusak }\end{array}$ \\
\hline & & Cukup & Samhong & Polybag & 50 & $\begin{array}{l}\text { Setelah } 2 \\
\text { minggu polybag } \\
\text { harus dipindah } \\
\text { ke bawah }\end{array}$ \\
\hline & & Banyak & Kale & $\begin{array}{l}\text { Kotak } \\
\text { tanah }\end{array}$ & 2 & Di lahan terbuka \\
\hline & & Banyak & Buncis & $\begin{array}{l}\text { Kotak } \\
\text { tanah }\end{array}$ & 1 & Di lahan terbuka \\
\hline & & Cukup & Baby Kailan & $\begin{array}{l}\text { Kotak } \\
\text { tanah }\end{array}$ & 2 & Di lahan terbuka \\
\hline & & Banyak & $\begin{array}{l}\text { Pakcoy } \\
\text { putih }\end{array}$ & Polybag & 100 & $\begin{array}{l}\text { Setelah } 2 \\
\text { minggu polybag } \\
\text { harus dipindah } \\
\text { ke bawah }\end{array}$ \\
\hline & & Cukup & $\begin{array}{l}\text { Pakcoy } \\
\text { naibai }\end{array}$ & Polybag & 50 & $\begin{array}{l}\text { Setelah } 2 \\
\text { minggu polybag } \\
\text { harus dipindah } \\
\text { ke bawah }\end{array}$ \\
\hline & & Banyak & $\begin{array}{l}\text { Pakcoy } \\
\text { lokal }\end{array}$ & Polybag & 100 & $\begin{array}{l}\text { Setelah } 2 \\
\text { minggu polybag } \\
\text { harus dipindah } \\
\text { ke bawah }\end{array}$ \\
\hline & & Banyak & Pagoda & Polybag & 100 & $\begin{array}{l}\text { Setelah } 2 \\
\text { minggu polybag } \\
\text { harus dipindah } \\
\text { ke bawah }\end{array}$ \\
\hline & & Cukup & Selada & Polybag & 50 & Sampai panen \\
\hline
\end{tabular}




\begin{tabular}{|c|c|c|c|c|c|c|}
\hline \multirow{15}{*}{ Februari } & \multirow{15}{*}{ Hujan } & Cukup & Kangkung & $\begin{array}{l}\text { Kotak } \\
\text { tanah }\end{array}$ & 2 & Di lahan terbuka \\
\hline & & Banyak & Bayam hijau & $\begin{array}{l}\text { Kotak } \\
\text { tanah }\end{array}$ & 0 & $\begin{array}{l}\text { Musim hujan, di } \\
\text { lahan terbuka, } \\
\text { bayam mudah } \\
\text { rusak }\end{array}$ \\
\hline & & Sedikit & $\begin{array}{l}\text { Bayam } \\
\text { Merah }\end{array}$ & $\begin{array}{l}\text { Kotak } \\
\text { tanah }\end{array}$ & 0 & $\begin{array}{l}\text { Musim hujan, di } \\
\text { lahan terbuka, } \\
\text { bayam mudah } \\
\text { rusak }\end{array}$ \\
\hline & & Cukup & Cabe Rawit & $\begin{array}{l}\text { Kotak } \\
\text { tanah }\end{array}$ & 1 & Di lahan terbuka \\
\hline & & Sedikit & Sosin & Polybag & 30 & $\begin{array}{l}\text { Setelah } 2 \\
\text { minggu polybag } \\
\text { harus dipindah } \\
\text { ke bawah }\end{array}$ \\
\hline & & Sedikit & Tomat & $\begin{array}{l}\text { Kotak } \\
\text { Tanah }\end{array}$ & 0 & $\begin{array}{l}\text { Musim hujan, di } \\
\text { lahan terbuka, } \\
\text { tomat mudah } \\
\text { rusak }\end{array}$ \\
\hline & & Cukup & Samhong & Polybag & 50 & $\begin{array}{l}\text { Setelah } 2 \\
\text { minggu polybag } \\
\text { harus dipindah } \\
\text { ke bawah }\end{array}$ \\
\hline & & Banyak & Kale & $\begin{array}{l}\text { Kotak } \\
\text { tanah }\end{array}$ & 2 & Di lahan terbuka \\
\hline & & Banyak & Buncis & $\begin{array}{l}\text { Kotak } \\
\text { tanah }\end{array}$ & 1 & Di lahan terbuka \\
\hline & & Cukup & Baby Kailan & $\begin{array}{l}\text { Kotak } \\
\text { tanah }\end{array}$ & 2 & Di lahan terbuka \\
\hline & & Banyak & $\begin{array}{l}\text { Pakcoy } \\
\text { putih }\end{array}$ & Polybag & 100 & $\begin{array}{l}\text { Setelah } 2 \\
\text { minggu polybag } \\
\text { harus dipindah } \\
\text { ke bawah }\end{array}$ \\
\hline & & Cukup & $\begin{array}{l}\text { Pakcoy } \\
\text { naibai }\end{array}$ & Polybag & 50 & $\begin{array}{l}\text { Setelah } 2 \\
\text { minggu polybag } \\
\text { harus dipindah } \\
\text { ke bawah }\end{array}$ \\
\hline & & Banyak & $\begin{array}{l}\text { Pakcoy } \\
\text { lokal }\end{array}$ & Polybag & 100 & $\begin{array}{l}\text { Setelah } 2 \\
\text { minggu polybag } \\
\text { harus dipindah } \\
\text { ke bawah }\end{array}$ \\
\hline & & Banyak & Pagoda & Polybag & 100 & $\begin{array}{l}\text { Setelah } 2 \\
\text { minggu polybag } \\
\text { harus dipindah } \\
\text { ke bawah } \\
\end{array}$ \\
\hline & & Cukup & Selada & Polybag & 50 & Sampai panen \\
\hline \multirow{3}{*}{ Maret } & \multirow{3}{*}{ Hujan } & Cukup & Kangkung & $\begin{array}{l}\text { Kotak } \\
\text { tanah }\end{array}$ & 2 & Di lahan terbuka \\
\hline & & Banyak & Bayam hijau & $\begin{array}{l}\text { Kotak } \\
\text { tanah }\end{array}$ & 0 & $\begin{array}{l}\text { Musim hujan, di } \\
\text { lahan terbuka, } \\
\text { bayam mudah } \\
\text { rusak }\end{array}$ \\
\hline & & Sedikit & $\begin{array}{l}\text { Bayam } \\
\text { Merah }\end{array}$ & $\begin{array}{l}\text { Kotak } \\
\text { tanah }\end{array}$ & 0 & $\begin{array}{l}\text { Musim hujan, di } \\
\text { lahan terbuka, } \\
\text { bayam mudah } \\
\text { rusak }\end{array}$ \\
\hline
\end{tabular}




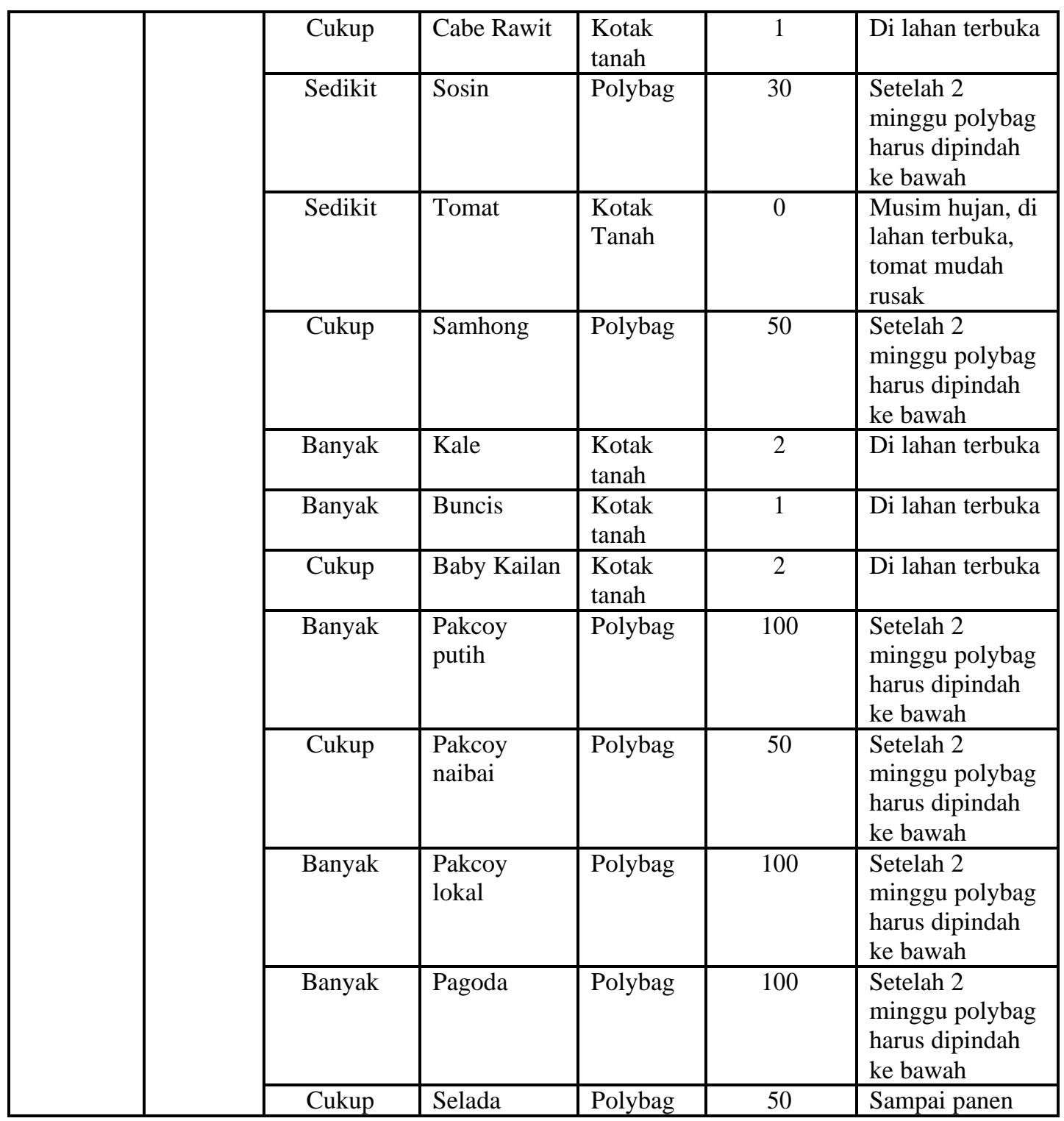

Sedangkan dokumen kegiatan pelatihan dan pendampingan penanaman di lapangan, tersaji pada Gambar 4 berikut
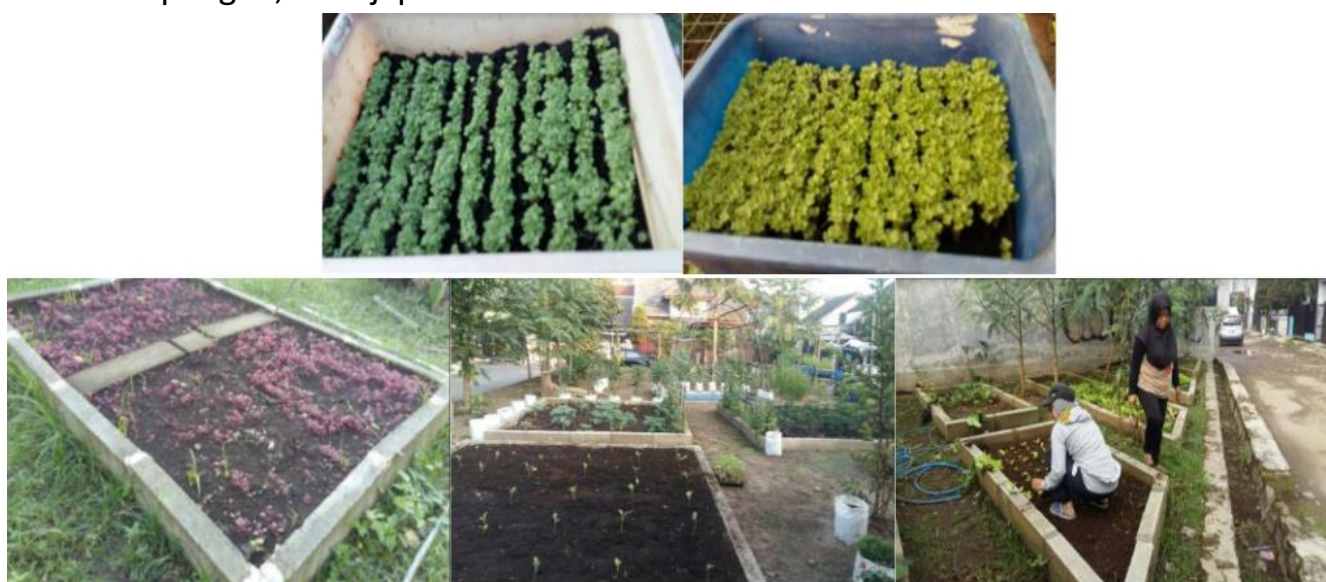

Gambar 4. Sosialisasi Program Pembuatan Kalender Masa Tanam 


\subsection{Evaluasi Kegiatan}

Evaluasi hasil pengabdian dilakukan berdasarkan hasil survey yang dilakukan terhadap masyarakat sasar. Parameter yang disurveykan tentang pelaksanaan sosialisasi, pelaksanaan pelatihan dan pendampingan serta hibah. Skala penilaian yang digunakan adalah: $1, \ldots, 5$ dimana 1 : SANGAT TIDAK SETUJU dan 5: SANGAT SETUJU (BAIK), Hasil survey yang diperoleh menyatakan $100 \%$ KWT membutuhkan dan puas dengan kalender masa tanam yang diusulkan. Point-point pertanyaan survei dapat dilihat pada tabel 2.

Tabel 2. Pernyataan Kuisioner

\begin{tabular}{|c|c|c|}
\hline No & Isi Pernyataan & Parameter yang di ukur \\
\hline 1 & $\begin{array}{l}\text { Sosialisasi program kegiatan dalam pengabdian } \\
\text { masyarakat ini sesuai dengan kebutuhan KWT } \\
\text { KREATIF PERMATA }\end{array}$ & $\begin{array}{l}\text { Kesesuaian program sosialisasi } \\
\text { dengan kebutuhan masyarakat } \\
\text { sasar }\end{array}$ \\
\hline 2 & $\begin{array}{l}\text { Apakah informasi yang disampaikan dalam setiap } \\
\text { kegiatan bagian dari pengabdian masyarakat ini } \\
\text { dapat menambah wawasan KWT KREATIF } \\
\text { PERMATA }\end{array}$ & $\begin{array}{l}\text { Kemanfaatan hasil sosialisasi } \\
\text { terhadap wawasan masyarakat } \\
\text { sasar }\end{array}$ \\
\hline 3 & $\begin{array}{l}\text { Apakah kegiatan diversifikasi olahan pangan } \\
\text { berbahan dasar produk sayuran organik KWT Kreatif } \\
\text { sudah sesuai dengan yang diharapkan? }\end{array}$ & $\begin{array}{l}\text { Kesesuaian harapan masyarakat } \\
\text { sasar dengan kegiatan diversifikasi } \\
\text { olahan pangan }\end{array}$ \\
\hline 4 & $\begin{array}{l}\text { Apakah kegiatan pengabdian masyarakat ini sangat } \\
\text { bermanfaat? }\end{array}$ & $\begin{array}{l}\text { Kemanfaatan diversifikasi olahan } \\
\text { pangan dalam menunjang } \\
\text { operasional KWT }\end{array}$ \\
\hline 5 & $\begin{array}{l}\text { Apakah nantinya setiap kegiatan yang menjadi } \\
\text { bagian dari pengabdian masyarakat ini dapat } \\
\text { dilaksanakan dengan baik di KWT Kreatif? }\end{array}$ & $\begin{array}{l}\text { Implementasi hasil kegiatan } \\
\text { pengabdian masyarakat }\end{array}$ \\
\hline 6 & $\begin{array}{l}\text { Apakah pemanfaatan media pemasaran online } \\
\text { sebagai sarana pengelolaan kegiatan pemasaran } \\
\text { olahan pangan sangat diperlukan oleh KWT Kreatif? }\end{array}$ & $\begin{array}{l}\text { Tingkat kebutuhan pemanfaatan } \\
\text { sosial media untuk mendukung } \\
\text { pemasaran olahan pangan }\end{array}$ \\
\hline 7 & $\begin{array}{l}\text { Apakah kegiatan perumusan masa tanam sayuran } \\
\text { organik di KWT KREATIF PERMATA sangat } \\
\text { diperlukan? }\end{array}$ & $\begin{array}{l}\text { Tingkat kebutuhan KWT akan } \\
\text { kalender masa tanam untuk } \\
\text { kekontinuan budidaya sayuran }\end{array}$ \\
\hline 8 & $\begin{array}{l}\text { Apakah pemanfaatan sayuran organik untuk olahan } \\
\text { pangan B2SA sudah sesuai dengan pengembangan } \\
\text { KWT KREATIF PERMATA }\end{array}$ & $\begin{array}{l}\text { Kesesuaian pemanfaatan hasil } \\
\text { budidaya tanaman sayuran dan } \\
\text { buah untuk olahan pangan }\end{array}$ \\
\hline 9 & $\begin{array}{l}\text { Apakah hibah media tanam untuk budidaya sayuran } \\
\text { organik, kalender masa tanam, resep, dan kemasan } \\
\text { untuk mendukung produksi sayuran sebagai bahan } \\
\text { dasar olahan pangan sangat bermanfaat bagi warga } \\
\text { sekitar dan warga di KWT KREATIF PERMATA }\end{array}$ & $\begin{array}{l}\text { Kebermanfaatan hibah output } \\
\text { pengabdian masyarakat untuk } \\
\text { kegiatan pemberdayaan warga dan } \\
\text { khususnya KWT KREATIF } \\
\text { PERMATA }\end{array}$ \\
\hline
\end{tabular}

Tingkat kebutuhan KWT akan kalender masa tanam untuk kontinuitas produksi sayuran
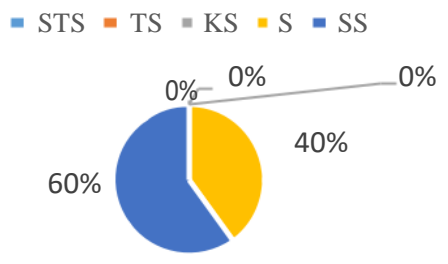

Gambar 3. Hasil evaluasi sebesar 100\% KWT membutuhkan kalender masa tanam 


\section{Kesimpulan}

Berdasarkan hasil yang diperoleh di atas, dapat disimpulkan bahwa kegiatan penyusunan kalender masa tanam yang merupakan bagian dari kegiatan pengabdian masyarakat kolaborasi ini sangat dibutuhkan dan bermanfaat bagi masyarakat sasar yaitu KWT Kreatif Permata dan dapat dilanjutkan ke pengembangan selanjutnya.

\section{DAFTAR PUSTAKA}

[1] (http://www.pikiran-rakyat.com/nasional/2017/09/29/potensial-kembangkanpertanian-kelompok-wanita-tani-belum-diberdayakan-410513).

[2] 